\title{
Access to the Brazilian agenda of the National Rural Water Supply and Sanitation Project (1985)
}

Nathalia Roland 1

Léo Heller 2

Sonaly Rezende 1

1 Universidade Federal de Minas Gerais / Postgraduate Program in Water Supply and Sanitation, Environment and Water

Resources, Belo Horizonte / MG - Brazil

${ }^{2}$ Fundação Oswaldo Cruz / René Rachou Institute, Belo Horizonte / MG - Brazil

This article seeks to understand the circumstances that culminated in the formulation and implementation of the National Rural Water Supply and Sanitation Project (PNSR) in the 1980s, using the Multiple Streams Model as its theoretical reference. The results show that the theme's ascension to the government agenda stemmed from a conjuncture marked by intense transitions that contributed to opening a policy window. The struggle to guarantee social rights in the Brazilian re-democratization process; the activities of social movements like the grassroots public health movement; the large sanitary deficit and its consequences for public health; the joint involvement of institutions with considerable expertise like Economic and Social Planning Institute (IPEA), Public Health Special Service Foundation (FSESP) and Pan-American Health Organization (PAHO) and the availability of financial resources stemming from a partnership arrangement with the International Bank for Reconstruction and Development (IBRD) provided a favorable environment for the elaboration of the PNSR.

Keywords: agenda-setting; multiple streams model; PNSR; public policy; rural water supply and sanitation.

\section{A entrada na agenda brasileira do Projeto Nacional de Saneamento Rural (1985)}

O presente artigo busca compreender as circunstâncias que culminaram na formulação e implementação, na década de 1980, do Projeto Nacional de Saneamento Rural (PNSR), adotando como marco teórico o Modelo de Múltiplos Fluxos. Os resultados evidenciam que sua ascensão à agenda governamental é decorrente de uma conjuntura marcada por intensas transições, que contribuíram para a abertura de uma janela de oportunidades. A busca pela garantia de direitos sociais no processo de redemocratização brasileiro; a atuação de movimentos sociais, como o movimento sanitarista; o grande déficit sanitário e suas consequências na saúde pública; o envolvimento conjunto de instituições com expertise, como o Instituto de Planejamento Econômico e Social (IPEA), a Fundação Serviço Especial de Saúde Pública (FSESP) e a Organização Pan-Americana de Saúde (OPAS) e a disponibilidade de recursos financeiros, provenientes de parceria com o Banco Internacional para Reconstrução e Desenvolvimento (BIRD), proporcionaram um ambiente favorável para a elaboração do PNSR.

Palavras-chave: formação da agenda; modelo de múltiplos fluxos; PNSR; política pública; saneamento rural.

\section{Inclusión en la agenda brasileña del Proyecto Nacional de Abastecimiento de Agua y Saneamiento Rural (1985)}

Este documento tiene como objetivo comprender las circunstancias que condujeron a la formulación e implementación, en la década de 1980, del Proyecto Nacional de Abastecimiento de Agua y Saneamiento Rural (PNSR), adoptando como marco teórico el modelo de flujos múltiples. Los resultados muestran que su ascenso a la agenda del gobierno se debe a una coyuntura marcada por intensas transiciones, que contribuyeron a la apertura de una ventana de oportunidad. La búsqueda de la garantía de los derechos sociales en el proceso de redemocratización brasileña; el desempeño de movimientos sociales, como el movimiento sanitario; el gran déficit de saneamiento y sus consecuencias en la salud pública; la participación conjunta de instituciones con experiencia, como el Instituto de Planificación Económica y Social (IPEA), la Fundación del Servicio Especial de Salud Pública (FSESP) y la Organización Panamericana de la Salud (OPS), y la disponibilidad de recursos financieros de una asociación con el Banco Internacional de Reconstrucción y Fomento (BIRF) proporcionó un entorno favorable para la elaboración del PNSR.

Palabras clave: formación de la agenda; modelo de flujos múltiples; PNSR; política pública; saneamiento rural.

DOI: http://dx.doi.org/10.1590/0034-7612201900392x

Article received on November 01, 2019 and accepted on May 12, 2020.

ISSN: $1982-3134$ CC (i)

[Original version] 


\section{ACKNOWLEDGEMENTS}

The authors wish to thank the Fundação de Amparo à Pesquisa do Estado de Minas Gerais (FAPEMIG) for the Ph.D. studies grant awarded to the first author, the Coordenação de Aperfeiçoamento de Pessoal de Nível Superior (CAPES) and the Conselho Nacional de Desenvolvimento Científico e Tecnológico (CNPq).

\section{INTRODUCTION}

In Brazil, water supply and basic sanitation in rural areas have not been the object of systematic, permanent actions on the part of the public authorities. There is considerable dispersion of the actions among a multitude of ministries and other bodies performing in an uncoordinated manner, along with a notable absence of long-term planning. Given that context, there has been a historical demand to have basic water supply and sanitation for rural areas included on the government agenda.

The Brazilian Law that establishes the national guidelines on potable water supply and basic sanitation establishes the universalization and equality of the respective services provision (Lei n. 11.445, 2007). In spite of that, urban centers have been prioritized in water supply and sanitation actions (Rezende \& Heller, 2008), contributing to the creation and maintenance of a considerable deficit of such services in rural areas. The present situation of water supply and sanitation in rural areas clearly shows how incipient the respective sector policies are and the great need for intensifying actions and investments in those areas. The 2010 Brazilian Demographic Census (Instituto Brasileiro de Geografia e Estatística [IBGE], 2011) showed that $37 \%$ of households in rural areas did not have internal piped water supply, $64 \%$ discharged domestic wastewater into rudimentary septic tanks and $11 \%$ discharged it directly into the environment.

That situation is not restricted to Brazil. While it is true that, worldwide, the difference between urban and rural areas in terms of potable water supply and basic sanitation service coverage has reduced in recent years, the overall inequality persists. Eight out of ten persons with no access to basic water supply services live in rural areas and roughly half of them are in least developed countries. In regard to sewage, seven out of ten persons with no access to sewage services live in rural areas and, of those, one third lives in least developed countries (Joint Monitoring Programme [JMP], 2019). Effective public policies for the sector are needed to overcome that situation.

Brazil is currently experiencing an important moment in its water supply and sanitation policy characterized by the publication of the National Rural Water and Sanitation Program ${ }^{1}$ (Fundação Nacional de Saúde [FUNASA], 2019), which was developed by the Universidade Federal de Minas Gerais, through oversight of the National Health Foundation (Funasa). It is well known that an analysis of previously implemented policies contributes towards the elaboration of more effective new policies given that such analyses enable an understanding how progress has been achieved and the difficulties encountered. Hall (1993) considers that those analyses constitute a policy learning

\footnotetext{
${ }^{1}$ At its launch, in December 2019, the Program received the name of Rural Brazil Water Supply and Sanitation Program (Portaria N. 3.174, de 02 de dezembro de 2019).
} 
process whereby public administrators endeavor to understand why certain initiative managed to be successful and why others failed.

One of the first planning initiatives at the national level for actions in the field of rural water supply and sanitation in Brazil was the National Rural Water Supply and Sanitation Project (PNSR), from 1985 to 1989. It was coordinated by an inter-ministerial committee made up of representatives of the Ministry of Health, the Ministry of Urban Development and the Environment and the Economic and Social Planning Institute (IPEA), with IPEA being designated as the project executor by the Planning Department of the Office of the Presidency (SEPLAN). The Pan-American Health Organization (PAHO/WHO) provided the technical assistance of national and international consultants during the formulation of the PNSR and the International Bank for Reconstruction and Development (IBRD), part of the World Bank Group, financed part of the project through a loan.

The PNSR was divided into the National Component and the Pilot-Project (Instituto de Planejamento Econômico e Social [IPEA], 1985). The National Component was responsible for conducting studies and providing technical assistance to support the Federal Government in defining pubic policies and preparing a ten-year rural water supply and basic sanitation program. Originally intended to be conducted in the state of Rio Grande do Sul, the Pilot-Project was transferred to the State of Minas Gerais. The idea was to expand projects at state level in order to provide important information to support the national component. The overall aim of the PNSR was 'to carry out basic work capable of establishing the roots of a permanent and long-lasting action' (IPEA, 1989a, p. 11).

As a result of the studies that made up the national component, in 1989 IPEA published the Rural Water Supply and Sanitation Series in nine volumes. Those documents expressed the PNSR concepts regarding rural water supply and sanitation provision in Brazil. The studies addressed aspects such as the planning and formulation of rural water supply and sanitation policies in the federal, state and municipal spheres of government, as well as the themes of administration, education, social participation, appropriate technology and human and financial resources.

The Pilot-Project (PPNSR) began in 1987 and was conducted by the Minas Gerais Water Supply and Sanitation Company (Copasa). The project aimed to provide water supply, sewage systems and domestic sanitation improvements to 230 rural communities with populations ranging from 200 to 2,000 inhabitants. Copasa officially terminated the PPNSR in 1994 having effectively reached out to just 136 communities (Dias, 1994).

It is believed that an analysis of the conjuncture at the time the PNSR was carried out can provide elements that enable a better understanding of the historically encountered problems and of the achievements that were obtained, thereby contributing towards the construction of present day rural water supply and sanitation policies. In their assessment of rural water supply and sanitation planning processes, Barnes, Roser, and Brown (2011) concluded that analyzing past efforts helps towards identifying the needs for new practices and benefits they could bring and fosters new planning processes.

The PNSR constituted an important planning process in the federal sphere. It was a project that involved various different national and international actors and fostered the generation of content for the sector throughout the period of its formulation, but it failed to achieve continuity. The implementation of the PNSR was limited to the Pilot-Project in Minas Gerais and was not 
propagated throughout the country. Studies have identified political-administrative discontinuity as one of the main hindrances to the development of public policies in Brazil (Fauré, 2005; Machado, Cotta, \& Soares, 2015). The interruption of projects has negative consequences that include the waste of public resources, loss of institutional knowledge and discouragement of the teams involved. With the interruption of the PNSR, Brazil spent the next 30 years without any planning addressing water and sanitation rural areas at the federal level. This situation changed only in 2019, with the publication of the National Rural Water and Sanitation Program (FUNASA, 2019).

With the aim of gaining an understanding of the motives that led to the elaboration of a national rural water supply and sanitation project in the political, social economic and institutional situation in which Brazil found itself in the mid-1980s, this article sets out to analyze the circumstances that led to a policy window for the PNSR to gain access to the government agenda.

There are various theoretical models that endeavor to explain the complex relations and the multiple variables that constitute the political processes from which public policies emerge. This article addresses the first stage of the process which consists of agenda-setting. It is the stage at which a given problem attracts government attention. That attention does not necessarily mean that the government will solve the respective problem but it does mean that it will rank alongside a society's other problems at the time in question (Howllet \& Ramesh, 2013).

The Multiple Streams Model (Kingdon, 1995) is the theoretical basis for this analysis. It has become a recognized reference model for studies dedicated to the analysis of government policy formulation processes and has been applied to a variety of areas (Jones et al., 2016), including health (Mannheimer, Lehto, \& Ostlin, 2007; Mauti et al., 2019) and water resource management issues (Font \& Subirats, 2010; Smith, Porter, \& Upham, 2016). It has also been used in other contexts ranging from studies at the local level (Liu, Lindquist, Vedlitz, \& Vincent, 2010) to studies of multilateral agenda-determining processes (Sumida, 2017).

Although it was developed in the USA context for the analysis of health and transport policies, the Multiple Streams Model has been widely applied to analyze case studies in the Brazilian context (Costa \& Rezende, 2016; Eça, Fracalanza, \& Jacobi, 2011; Ferreira, 2013). It has been also addressed in theoretical analyzes that carry out a critical interpretation of this model, its features and potential applications (Capella 2006; Capella, Brasil, \& Sudano, 2015; Gottems, Pires, Calmon, \& Alves, 2013). These studies generally emphasize the flexibility of the method and attest that articulation between definition of the problem, definition of alternatives and the political process, proposed by Kingdon (1995), is productive to explain the innovations in the public agenda. However, they emphasize the importance of applying the model taking into account the local reality to be analyzed and its historical context.

The ample variables that Kingdon (1995) proposed make it possible to elucidate the subjectivity involved in the decision-making process. For that reason, Zahariadis (1998) considers that it is a suitable method for describing how governments define national agendas when there is ambiguity of objectives or there are unstable environments in which choices depend on the context. Those two characteristics are coherent with the historical period that the PNSR was part of and they were associated to the re-democratization process in course in Brazil at the time, after a period of military dictatorship that had lasted twenty years. 


\section{METHODOLOGY}

In the Multiple Streams Model the three decision-related streams - problems, policies and politics follow their courses independently until whenever a critical situation creates the necessary conditions to open a policy window that will lead to changes in the agenda (Kingdon, 1995).

In the problem stream the model seeks to analyze it in order to interpret the way problems are recognized and why, in the midst of such a great array of problems, only some come to occupy a place on the government agenda. That process may take place through three mechanisms: monitoring indicators; events and crises; and feedback from government actions (Kingdon, 1995).

With the second stream, policies, the central issue is to get to know how the ideas capable of providing solutions to a given problem are generated. The alternatives are generated by communities made of governmental or non-governmental experts who share a common concern for a certain area of interest. Ideas emerge, are combined or recombined with one another, and at the heart of those dynamics, some disappear while others survive and prosper (Kingdon, 1995).

The third stream concerns the political dimension and involves political happenings, considered to be powerful agenda determiners. Irrespective of the recognition of a problem or of the available alternatives, the political stream follows its own rules and operates its own dynamics (Kingdon, 1995).

This study conducted a mapping of the three streams that Kingdon (1995) proposed based on the extant political, economic, social and institutional contexts of Brazil in the 1980s, seeking to associate them to the formulation of the PNSR. Following that, an analysis was made as to whether, the combination of the three streams had propitiated a policy window that had made it possible to place rural water supply and sanitation among the overall set of government policies.

The empirical basis of the study was interviews carried out by the fist author and documents retrieved and analyzed in the context of this research. Documents include: official public documents, such as documents that provided support to the elaboration of the PNSR, available at the IPEA and Copasa libraries (IPEA, 1989a, 1989b, 1989c); documents related to the Pilot-Project (Dias, 1994; Ennes, 1990); and legal documents (Brasil, 1985; IPEA, 1985; Portaria Interministerial N. 55, de 19 de dezembro de 1984; Portaria Interministerial N. 30, de 28 de fevereiro de 1985). Content analysis (Bardin, 2011) was adopted for both the outcomes of the interviews and the documents assessed.

The verbal material was obtained from 14 semi-structured interviews (Flick, 2011) with key-actors who had either actually participated in the formulation of the PNSR in the federal sphere or in the implementation of the Pilot-Project in the state of Minas Gerais. To ensure the anonymity of research participants, the following identification codes were adopted for the interviewees: IP - technical staff of IPEA; MH - technical staff of the Ministry of Health; MUD - technical staff of the Ministry of Urban Development and the Environment; COP - technical staff of COPASA; and PA - consultants hired by PAHO. This study was approved by the Research Ethics Committee of the Federal University of Minas Gerais (CAE 88462318.6.0000.5149). 


\section{RESULTS AND DISCUSSION}

\subsection{The problem stream}

Rural inhabitants' poor level of access to basic water supply and sanitation services, the high incidence of parasite-related diseases and infectious diseases among them and the mass migration of the rural populations to the big cities can readily be identified as national outstanding problems that were associated to the formulation of the PNSR.

At that time, the water supply and sanitation situation in Brazil's rural areas was typified by the absence of any adequate service provision. According to data of the 1980 Demographic Census (IBGE, 1981), 83\% of persons inhabiting rural areas did not have access to internal domestic water supply and $62 \%$ of them discharged their wastewater in the open air or directly into the environment. An interviewee referred to 'a low level of coverage [of water supply and sanitation services] at the time. Planasa $a^{2}$ did not have any proposal for the rural areas so that [the PNSR] came to complement Planasa's actions' (MH01).

Indeed, Planasa came to represent a milestone in the area of water supply and sanitation in Brazil because of the actions undertaken coupled with the broad economic investments. Nevertheless, the differences between urban and rural areas increased in regard to government actions with a notably unequal distribution of access (Saiani \& Toneto, 2010).

That water and sanitation situation in rural areas was most certainly associated to the public health situation in a period in which there was a high level of occurrence of infectious diseases and parasite-related diseases. In the interpretation of one of the interviewees, the mobilization around an agenda for rural water supply and sanitation 'also had something to do with health issues. The diseases that occurred, especially in the rural areas, the neediness and grievances, all of that must also have carried weight in the decision. In a context that was highly favorable; in 1986, the grassroots public health movement was very strong' (PA03).

Those malaises, which mainly affected the populations inhabiting rural areas, began to appear in urban areas as well (Paim, Travassos, Almeida, Bahia, \& Macinko, 2011). In the extant context of globalization, reforms and the aftermath of the economic crisis experienced in the 1980s, there was a new surge, in Brazil, of migration of the rural population to the urban areas (Perz, 2000). One of the interviewees underscored the importance of developing a water and sanitation policy capable of 'making people remain in the rural areas. Brazil was undergoing highly accelerated urban expansion. It was something that we stated in all our publications at the time. That was one of the gains [of the PNSR], keeping people there' (COP05).

After a period of industrialization during the 1950s, 60s, and 70s, various political, economic and social transformations took place in Brazil with repercussions for its demographic dynamics and affecting migratory patterns and morbidity/mortality indexes which, in turn, intensified demands related to the health and sanitation sectors (Cunha, 2005). In the urban centers, the absence of any

${ }^{2}$ The National Water Supply and Sanitation Plan, instituted in 1971. Planasa declined with the economic crisis Brazil experienced in the 1980s. 
proper planning led to the formation of disorganized populational agglomerations with low levels of infrastructure provision and poor living standards. In that light, any actions capable of fostering the retention of rural migrants in their places of origin were encouraged.

In regard to the problems stream, Kingdon (1995) states that when the indicators reveal the existence of an issue, public policy formulators may perceive it as a problem and that arouses the need to take action. In Brazil of the 1970s and 1980s, the sanitary and socioeconomic indicators were alarming. The mortality statistics that the Ministry of Health published in 1980 indicated a high rate of deaths from infectious and parasite-related diseases, especially among children in the first year of life and in the age group 1 to 4 (Barros, 1984). More specifically, in regard to inadequate environmental sanitation-related diseases, the mortality rate in Brazil was 30 deaths per 100 thousand inhabitants. In the macro-regions with lower percentages of water and sanitation service provision such as the North and the Northeast, those rates were as high as 48 and 39 deaths per 100 thousand, respectively (Funasa, 2010).

The Brazilian public health situation revealed a panorama of outstanding needs and necessities. It was precisely against that background of water supply and sanitation crisis and all the problems mentioned above, that the perception arose of the need for a reformulation of the rural water supply and sanitation sub-sector and the elaboration of an appropriate national policy. After conducting studies in Brazil, in 1983, the World Bank delivered its report entitled 'Study of selected water and wastes sector issues: rural water supply and sanitation' to the Brazilian federal government. One of the document's recommendations was that the IBRD should consider the possibility of contributing to the development of rural water supply and sanitation in Brazil. That led the National Bank of Housing (BNH) to request SEPLAN to set priority on promoting efforts in that area (IPEA, 1985).

So, as one of the interviewees related, the IPEA undertook studies and later, in 1985, negotiations began that led to the beginning of the PNSR: 'Ottani [IPEA coordinator of the PNSR] went to Washington to negotiate the World Bank loan. There was a document, a kind of diagnosis, of the water and sanitation situation in Brazil, especially of the rural situation, and it showed the contrast between the urban water supply and sanitation and the lack of assistance for the rural areas. And based on that document, the federal government, through the IPEA, the Ministry of Health and the Ministry of Urban Development, decided to go ahead with the project' (PA01).

\subsection{The policy stream}

Kingdon (1995) proposes that the alternatives and solutions can be gradually constructed by means of a process involving debates, hearings, draft legislation etc. In the mid-1970s, the debate on health issues became increasingly expressive in Brazil. At that time a movement in favor of a Brazilian public health reform gained momentum, seeking to overcome the rigid limits imposed by the authoritarian regime and to introduce progressive changes in the organizational base of the country's health system. In the wake of that movement, based on a vision of health as a right, various proposals for structural and political change in Brazil emerged.

It must stressed that at the same time there were intense activities broadcasting ideas and agglutinating critical thinking in regard to health and innumerable conferences and debates were 
organized. Outstanding among them was the 8th National Health Conference (CNS), held in 1986. The report of that conference presented a set of articulated policies demanded by the public health movement and it eventually provided support for the elaboration of the chapter of the 1988 Constitution referring to health. The public health reform movement was also present in the post-1988 scenario when the process to develop the Unified Health System (SUS) was in course; one which consolidated the principles embraced by the Constituent Assembly such as equality, integrality and universality (Paiva \& Teixeira, 2014). Furthermore, as Paiva (2016) has pointed out, the rural water and sanitation agenda, clamored for by international bodies such as PAHO and by various other national social actors and public health movements, was by no means an entirely new topic within the framework of the country's health policies.

That historic moment for the public health field brought with it innovations and questionings that influenced the government actors involved in formulating the PNSR and did so in a context of political reopening and re-democratization, which were both underscored by an interviewee who identified 'a very favorable climate for understanding a little more about the needs of the poorer, less assisted population. In the field of health, the National Health Conferences had a very strong influence [on PNSR elaboration]' (MUD01). In that context, the need to construct a new social and political model was reflected in the guiding principles of the PNSR because it was: ' $a$ time when the population was experiencing democracy. Many democratic tendencies participated in the government, and that was highly important because those convictions were to appear in the text [of the Rural Water Supply and Sanitation Series]' (MUD01).

Given that favorable environment of effervescent discussion, there was a need for an apparat that could operationalize a national rural water supply and sanitation project as well as for the technical and financial resources that would make its execution feasible. IPEA, which was attached to the SEPLAN, elaborated the PNSR. An important fact to take into account in an analysis of the period being studied is that the institutional spaces were occupied by technical officers who did not reproduce the dominant policy of the day but, on the contrary, endeavored to defend alternative, counter-hegemonic proposals (Escorel, 1999). Although a neoclassic economist was in charge of IPEA's coordination of the PNSR, which could leave it open to criticism, nevertheless there was freedom of discussion of ideas as one of interviewees pointed out: 'we enjoyed freedom [in formulating the PNSR]. Our coordinator was somewhat rigid, he was always trying fence us in, but at least in terms of discussion we were free to discuss everything!' (PA02).

Again in the institutional context of the PNSR formulation, there was the participation of the Public Health Special Service Foundation (FSESP), an institution with a performance already consolidated in the country. One of the features of FSESP from its beginning was its proximity to local authorities and its consequent capillarity throughout Brazilian territory. One of the interviewees highlighted that vocation: 'FSESP entered [the PNSR formulation process] because of its rural experience. It had health care units and together with them it had sanitation workshops that worked alongside the communities to carry out domestic sanitation improvements, installing septic tanks; it worked a lot along those lines' (MH01).

Although the entity had a very strong technical and sometimes even authoritarian nature, it was acknowledged as an institution with years of activity and experience throughout the land and especially in localities with small populations and rural areas thereby constituting a suitable environment for supporting the development of rural water supply and sanitation projects. 
Lastly, the partnership arrangements with international bodies provided the much-needed technical and financial support to foster the PNSR. In technical terms, the PNSR enjoyed the support of PAHO, an entity that was expanding its activities and already had partnership arrangements in place with the Brazilian government designed to qualify Brazilian health workers (Paiva, Pires-Alves, \& Hochman, 2008). Ever since the 1960s, after the Economic Commission for Latin America and the Caribbean's (ECLAC) diffusion of health planning in the region, PAHO had been responsible for providing advisory services for policy elaboration in those countries that received financial resources from the international financing agencies and also for evaluating the elaborated projects in regard to their achievement of the pre-established goals (Giovanella, 1991).

The United Nations Organization (UN) designated the period 1981 to 1990 as the 'International Drinking Water Supply and Sanitation Decade. Over that period, one of PAHO's main fields of activity was indeed water supply and sanitation and, in a broader interpretation, environmental health, and it set priority on achieving its sanitation and environmental health goals in Latin America. It was possible to observe the gradual consolidation of sanitary engineering within that institution and the execution of various technical cooperation initiatives in that field (Lima, 2002). Thus the institution contributed to the PNSR the experience it had acquired in formulating policies directed at rural communities all over Latin America. As one of the interviewees explained: '[The PNSR] was a project involving various actors and there was a negotiation to bring in the World Health Organization. The PAHO staff, who brought with them their experience in working with communities, developed all of the Project's technical content. They already had a certain amount of experience in Latin American countries and so we established a cooperation agreement' (IP01).

The IBRD financed the PNSR and one outstanding feature of the 1980s was the World Bank's involvement in the political and economic affairs of Latin American countries (Vilas, 2015). Previously the Bank had limited its activities to financing investment projects, but in the 1980s it began to go beyond its original function, recommending and supervising public policies of national states affected by the international crisis. The various interviewees had different perceptions of the IBRD's influence on the PNSR. One person underscored the Bank's monitoring role: 'people from the bank came to the follow-up meetings. People from the area of sanitation, who had knowledge of actions all over the world. But they did not influence Program contents in any way' (MUD01). Other interviewed emphasized the technical suggestions: 'As the World Bank had really notable international experience, it took advantage of it. I remember the appropriate technical suggestions that were put forward, various simplified alternative systems based on experiences in other countries. So there was that kind of influence, but they did not demand anything; there was no inducement'(PA01).

Thus there was a social and institutional conjuncture conducive to the formation of the policies stream and that culminated in the elaboration of the PNSR. In the national sphere, the moment was one of intense debates, especially in the health sector, and it propitiated the emergence of associated issues such as rural water supply and sanitation, especially because that particular issue was already present and the focus of activities of institutions involved in that field like IPEA and FSESP. Internationally, the experience of PAHO and the IBRD involving water supply and sanitation in rural communities in Latin America and the world at large, provided a much broader theoretical and empirical framework for PNSR development. 


\subsection{The politics stream}

Kingdon (1995) maintains that it is the dynamics of the politics stream that determines the importance of a given theme for the government agenda independently of the other two streams (problem and policy) insofar as the politics stream has its own rules. It is a stream influenced by the national mood, by the formation of coalitions and interest groups, and changes of government. Kingdon (1995) also identifies the electoral process as one of the predominant factors involved in establishing an agenda.

In the 1980s the Brazilian context was marked by instability and the occurrence of profound alterations. The change in situation at that time was associated to the end of the military dictatorship (1964-1984), the indirect election of a civil government (the Sarney administration, 1985-1989) and subsequently, the direct election of Fernando Collor as President of the Republic (1990-1992). The military government that had preceded those two civil elections had a strong influence on the politics of the period under study and it cannot be ignored.

While in the economic field Brazil was experiencing the passage from a developmentalist period with a high level of economic growth in the 1970s to one of crisis and recession during the 1980s, in the political context it was undergoing a slow and gradual opening process and, in the social context, one of strengthening grassroots movements and political organization. The crisis that came in the wake of the 'economic miracle' exacerbated discontentment with the military regime. It became the target of harsh criticism and was especially accused of having accentuated regional and social differences and concentrating income in the hands of the rich. Although the country had achieved an economic growth rate of around $10 \%$ a year, the military regime had been incapable of reducing social injustice. Instead there had been a notable economic concentration, with high inflation and an increase in the external debt that foreshadowed the advent of a far greater social crisis (Silva, 1990). Thus, from the mid-1970s on there were intense grassroots movements in Brazil clamoring for reforms in social policies and, among those, in health policy.

The struggle for re-democratization took on new features and adopted new strategies. Clandestine groups and social movements formerly restricted to the universities began to become located within the state itself. In 1982, for the first time in twenty years, free elections for the National Congress and the legislative assemblies were held, electing representatives, mayors and councilors many of whom had health issues as part of their political platforms and in general had some kind of connection with the issue of re-democratization (Fleury, 2009; Luz, 1991; Menicucci \& D’Albuquerque, 2018). Escorel (2005) states that the public health movement was also very active in government circles through the presence of technical staff, thereby contributing to the achievement of reforms in the then extant policies: 'many things became feasible because persons linked to that [public health] movement were hired as technical staff due to their curricula; their technical qualifications. And within the institutions they managed to bring about small changes'.

In regard to the PNSR, one of the interviewees underscores how the political moment Brazil was going through encouraged the technical staff involved to apply their ideas in conducting the Project: 'The PNSR was able to function as a safety valve for us to let out many of the ideas that had always existed prior to, during and after the military regime, but that had remained hidden. And many of the people there, including myself, had been involved at some time in student movements, in the $8^{\text {th }}$ National Health Conference, which was a milestone, and with the ideas of Paulo Freire' (PA02). 
All that democratic effervescence was channeled into the work of the National Constituent Assembly and in 1988 the new Brazilian Constitution was enacted, embodying considerable progress compared to earlier legislative formulations and guaranteeing Brazilian people a broad range of social rights.

The changes that took place during the government of President José Sarney were marked by a critical attitude towards the institutional and financial centralization of the system inherited from the military governments. At the beginning of the Sarney government the various government action plans conceived set priority on quitting the 'social debt' and the possibility of subjecting social policies to macro-economic adjustment measures was rejected. The slogan in the early days of that government was 'everything for the social [side]'. In the two-year period 1985-1986, the main line of reformist actions carried out by the federal executive consisted in setting up sector-based committees and working groups (Risi \& Nogueira, 2002). In that light the institution of an inter-ministerial Rural Water Supply and Sanitation Committee to formulate the PNSR was in natural alignment with the logic guiding the Federal Government at the time. However, as the country's economic situation began to deteriorate, the policies intended to be social and democratic were gradually replaced in the second stage of the Sarney government by more conservative and authoritarian proposals (Escorel, 1999). The PNSR emerged in the midst of those political dynamics.

It should be noted that in the international context of the day neoliberal ideals supported by multilateral bodies like the World Bank and the International Monetary Fund began to gain force, pressuring peripheral countries to adopt a political program based on no trade restrictions, financial deregulation, broad deregulation of the economy as a whole and the privatization of public companies; a development model that was supposedly valid for all societies (Pereira, 2015).

\subsection{The policy window}

In his Multiple Streams model, Kingdon (1995) refers to the moment when the three streams converge as coupling. At that moment a problem is recognized, a solution is available and the political conditions make the moment propitious for change and for the issues involved to access the agenda. The circumstances that make the convergence of the streams possible constitute a policy window and they are influenced, above all, by the problems stream and the politics stream. Kingdon (1995) explains that the policy stream has no direct influence on the policy window, given that the proposals, solutions and alternatives that are elaborated only get on the agenda when the problems have been perceived or the political demands create opportunities for the respective ideas to emerge.

An important actor contributing to the integration of the streams is the policy entrepreneur. When the policy window opens, such individuals, who may or may not be part of the government, play a fundamental role in uniting solutions with problems; proposals with political moments; and political events with problems (Kingdon, 1995).

In the case under study, as set out earlier in the text, the problems that existed in rural Brazil that included the migrations of rural populations to the cities, the lack of proper water supply and basic sanitation solutions and the high incidence of infectious and parasite-related diseases were readily perceptible on analyzing the respective indicators of the day. Those problems came 
to the government's attention when the World Bank delivered a report which led the Brazilian government to prioritize a set of studies and diagnoses of the respective area with the aim of negotiating an IBRD loan at some time in the future. In the social sphere there was, at that time, an intellectual effervescence and social movements were being reorganized; all of which influenced the ideas of government technical staff some of whom were engaged in the elaboration of the PNSR. Concomitantly, in the national politics stream, the moment was propitious for a discussion of social policies and the health sector proved to be of great importance in the context of the reformulation of democracy in Brazil. That was the configuration of the streams, each one following its own course, in the second half of the 1980s

The convergence of the streams was brought about by a request from the government of the state of Rio Grande do Sul to the BNH for the latter to capture external financial resources from the IBRD. The project that the state government had elaborated was submitted to one of the federal government's planning bodies, the IPEA, for evaluation. In a technical opinion, an IPEA's analyst rejected continuity of the project arguing that the absence of any education actions or social participation measures would jeopardize the effectiveness of the actions the project was proposing to implement. As a result of that decision, a series of discussions took place which culminated in the development of the PNSR as described in the following account: 'I decided to investigate the matter and issued a contrary technical opinion because of the question of community education which needed to be more thoroughly studied. That led to an imbroglio. People appeared from the World Bank, the BNH the vice-president of the IPEA... I commented that the water and sanitation issue called for a different approach, the project needed a new arrangement. After that there were various discussions. (...) In short, they agreed to develop a national project that the IPEA would coordinate but also involving FSESP and financed by the Bank. We were not expecting that. It was not the original intention. It was, however, the solution that they found and that was how the project began' (IP02).

In May 1985, as a result of those discussions, loan agreement 2532-BR was signed for the 'Pilot-Project and technical assistance project for water supply and waste treatment in rural areas' for which the IBRD would finance the Federative Republic of Brazil. The process of forming a team to conduct the National Component of the Project began, based on the institution of an inter-ministerial committee in December 1984. Initially Rio Grande do Sul was responsible for the Pilot-Project but in 1987, because of that state's indebtedness, it was replaced by the State of Minas Gerais.

Thus it can be seen that interviewee IP02 performed as an important policy entrepreneur. By questioning the initial proposal for investing in rural water and sanitation actions in a Brazilian state, that government technical officer involuntarily contributed to setting in motion a process which after a series of negotiations among the actors involved, would result in the coupling of the three streams which, in turn, provoked awareness of the need for national planning for the execution of water supply and sanitation actions in Brazil's rural areas. At that moment, in the light of all the nationally well-known problems, the favorable political dynamics and the availability of a solution in the form of a project in the federal sphere conducted by IPEA and financed by the IBRD, the theme of rural water supply and sanitation finally took its place on the public agenda. Figure 1 presents a synthesis of the three streams, showing processes that led to a policy window. 

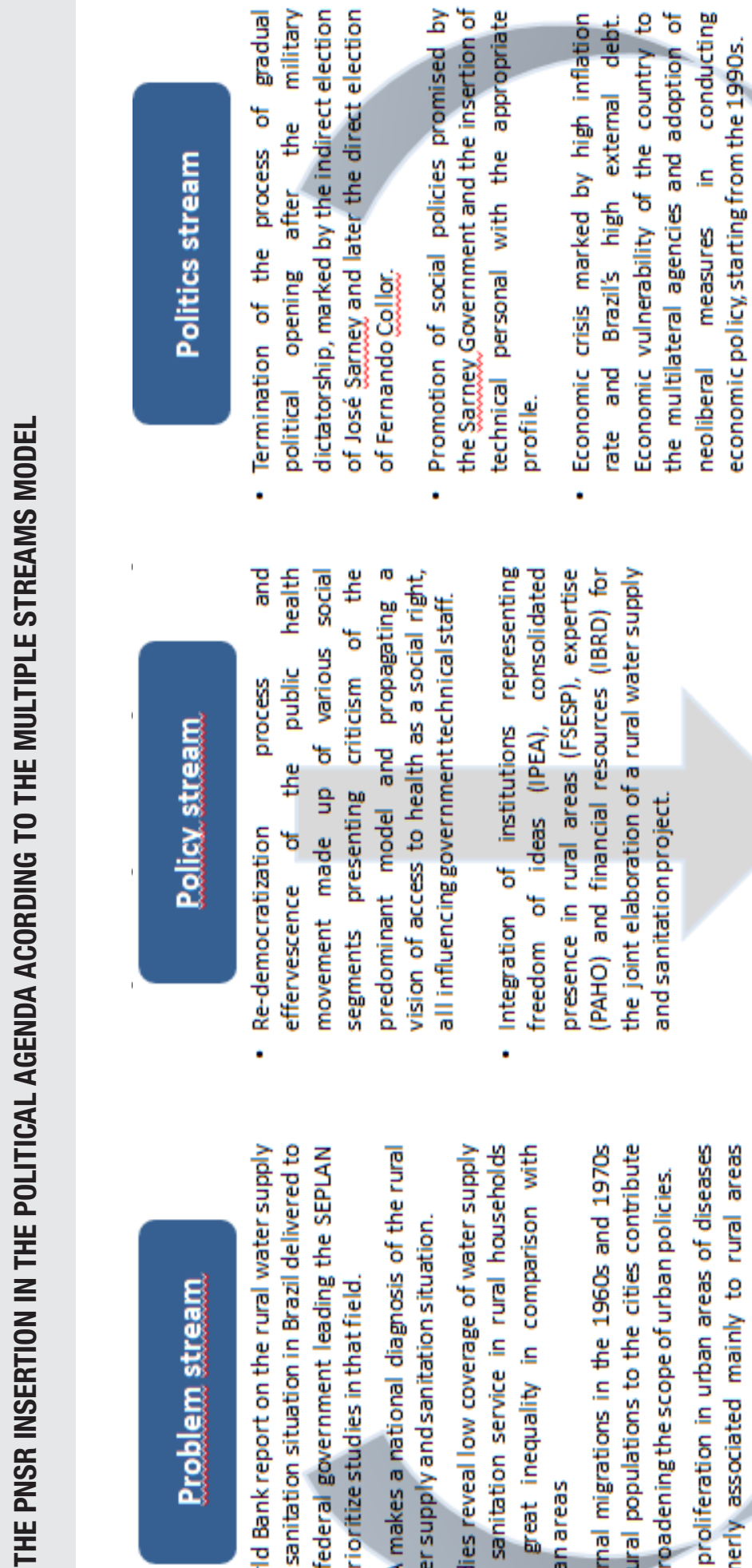

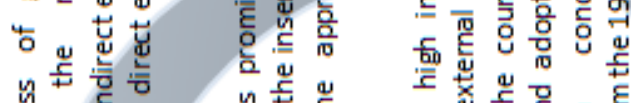

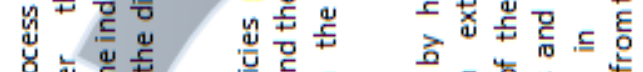

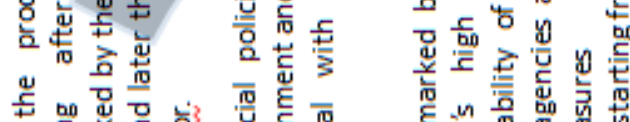

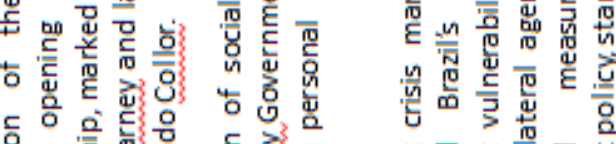

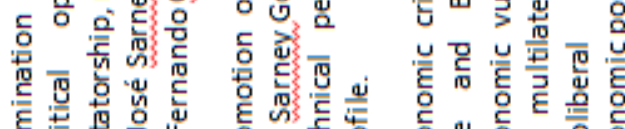

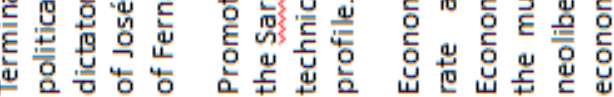

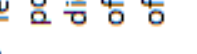

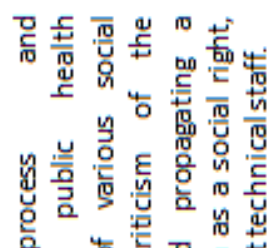

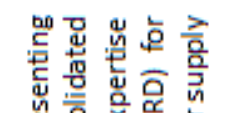

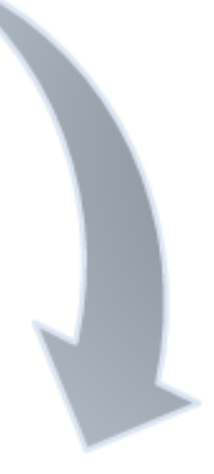

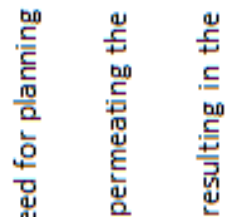

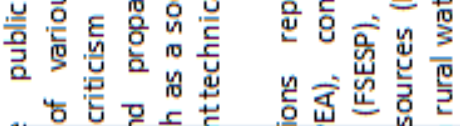

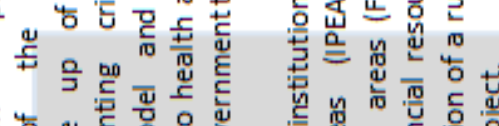

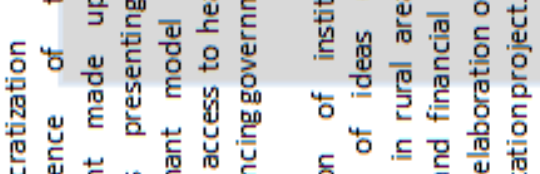

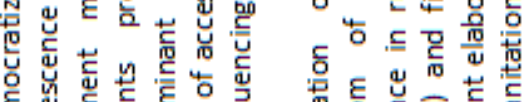

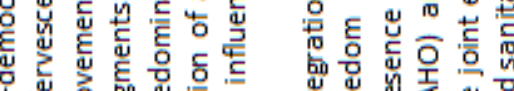

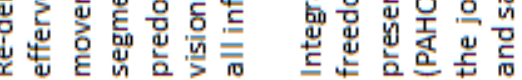

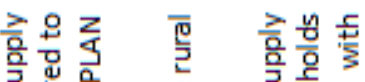

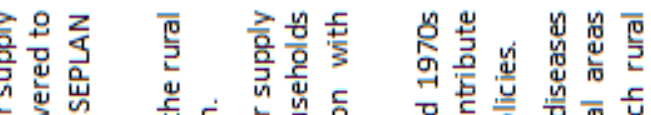

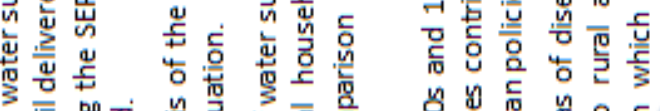

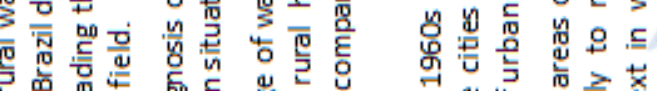

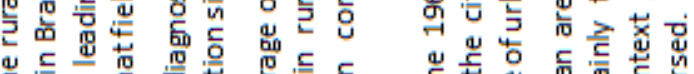

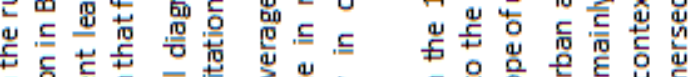

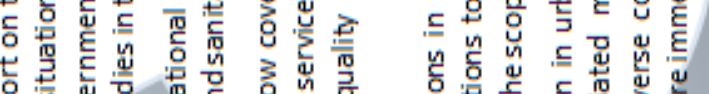

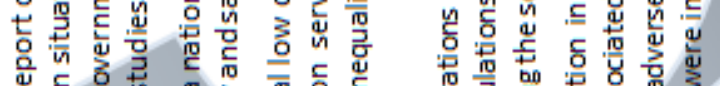

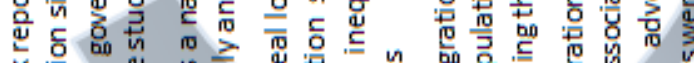

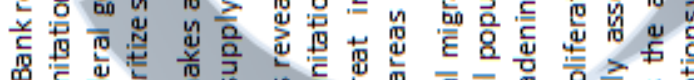

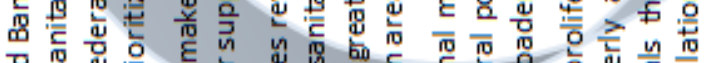

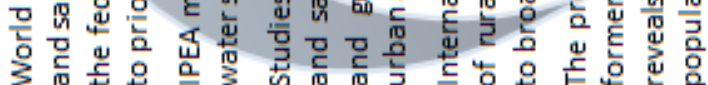




\section{CONCLUSIONS}

This article set out to analyze the circumstances that culminated in the opening of a policy window enabling the National Rural Water Supply and Sanitation Project to be inserted on the government agenda. The analyses provided evidence that the ascension of rural water and sanitation to the agenda stemmed from the situation of intense transitions that Brazil was experiencing at the time. The problems stream, namely, low coverage of water supply and sanitation services in rural areas, high incidence of diseases and exodus of populations from rural areas aroused awareness of the need for greater action and for studies to support the performance of water supply and sanitation actions in rural areas, especially after the delivery of the World Bank report, indicating the urgent need to develop that sub-sector.

The political stream was also of considerable importance in getting the PNSR onto the government agenda given the indirect election of José Sarney in 1985 and his government's elaboration of social policies. The struggle to obtain guarantees for social rights in the Brazilian re-democratization process in the political context and the vigorous performance of social movements had impacts on those government technical officers responsible for elaborating the Project.

In the policy stream, the involvement of a set of different institutions with valuable expertise such as IPEA, FSESP and PAHO, and the availability of financial resources from IBRD loan, created a favorable environment in which to conduct the Project. The coupling of the three streams actually came about through the actions of a policy entrepreneur who involuntarily contributed to the negotiating process that was to result in the formulation of the PNSR.

The Multiple Streams Model that served as the theoretical reference for this study proved to be adequate insofar as it enabled the detection of factors related to how rural water and sanitation gained access to the government agenda, propitiating the elaboration of the PNSR. It must be stressed that the institutions themselves played an important role in the ascension of the study object to the government agenda. Although the model that Kingdon originally published does not contemplate those actors, that did not prevent them from being inserted in the analysis because of the fluid nature of the theory. Accordingly, it is believed that the Multiple Streams Model offers flexibility to the analysis of public agenda formation and assists in constructing the extant macro-economic situation conjuncture, making it applicable to a variety of different contexts and realities.

After accessing the agenda, the PNSR implementation was hampered. Factors such as the Brazil's economic crisis, the consequent recession and the government's inability to finance public policies may have affected the Project's continuity. The changes in the political situation, with the election of Fernando Collor in 1990, and the institutional reorganization promoted by the new government may have contributed to the decoupling of the three streams and the closing of the policy window. A deeper exploration of the reasons for the PNSR failure, mapping the key conditioning factors in a more accurate way would be a recommended study, which would contribute to the understanding political discontinuities in the water and sanitation sector in Brazil. 


\section{REFERENCES}

Bardin, L. (2011). Análise de conteúdo (5a ed.) Lisboa, Portugal: Edições 70.

Barnes, R., Roser, D., \& Brown, P. (2011). Critical evaluation of planning frameworks for rural water and sanitation development projects. Development in Practice, 21(2), 168-189.

Barros, M. B. A. (1984). Considerações sobre a mortalidade no Brasil em 1980. Rev. Saúde Pública, 18(2), 122-137.

Brasil. (1985). Projeto de estudos, assistência técnica e reorganização institucional do subsetor de saneamento básico rural. Termos de Referência. Documento de trabalho, 05 de julho de 1985. Brasília, DF: Author.

Capella, A. C. N. (2006). Perspectivas teóricas sobre o processo de formulação de políticas públicas. Revista Brasileira de Informação Bibliográfica em Ciências Sociais, 61, 25-52.

Capella, A. C. N., Brasil, F. G., \& Sudano, A. D. C. G. P. (2015). O estudo da agenda governamental: reflexões metodológicas e indicativos para pesquisas. In Anais do $39^{\circ}$ Encontro Anual da ANPOCS, Caxambu, MG.

Costa, O. S., Filho, \& Rezende, S. (2016). O saneamento na agenda pública: a dinâmica política e a implantação dos serviços em Rio Branco, Acre. Revista Brasileira de Gestão e Desenvolvimento Regional, 12(1), 331-354.

Cunha, J. M. P. (2005). Migração e urbanização no Brasil: alguns desafios metodológicos para análise. São Paulo Perspec., 19(4), 3-20.

Dias, M. G. (1994). Frutos mirrados. Revista Bio, 6(2), 7-10.

Eça, R. F., Fracalanza, A. P., \& Jacobi, P. R. (2013). A problemática da água na agenda governamental do estado de São Paulo (1920-1991). Revista Política Pública, 17(1), 49-58.

Ennes, Y. M. (1990, Oct./Dec.). Contribuição à memória do saneamento rural em Minas: operacionalização e avaliação dos programas estaduais. Revista Bio, 50-55.

Escorel, S. (1999). Reviravolta na saúde: origem e articulação do movimento sanitário. Rio de Janeiro, RJ: Editora Fiocruz.
Escorel, S. (2005). Depoimento da médica sanitarista Sarah Escorel (ENSP/Fiocruz) fornecido em 14/04/2005 ao projeto 'Memória e Patrimônio da Saúde Pública no Brasil: a trajetória de Sérgio Arouca'. Rio de Janeiro, RJ: Programa de Pós-Graduação em Memória Social da Universidade Federal do Estado do Rio de Janeiro. Retrieved from http://www. memoriasocial.pro.br/linhas/arouca/depoimentos/ depoimentosarahescorel.htm

Fauré, Y. A. (2005). Des politiques publiques décentralisées, entraves au développement local: expériences brésiliennes. Revue Tiers Monde, 181(1), 95-118.

Ferreira, A. M. (2013). Projeto de transposição de águas do Rio São Fansicso: uma análise do processo de agenda-setting (Master Thesis). Fundação Getúlio Vargas, São Paulo, SP.

Fleury, S. (2009). Reforma sanitária brasileira: dilemas entre o instituinte e o instituído. Ciência \& Saúde Coletiva, 14(3), 743-752.

Flick, U. (2011). Introdução à pesquisa qualitativa. Porto Alegre, RS: Artmed.

Font, N., \& Subirats, J. (2010). Water management in Spain: The role of policy entrepreneurs in shaping change. Ecology and Society, 15(2), 25-38.

Fundação Nacional de Saúde. (2010). Impactos na saúde e no sistema único de saúde decorrentes de agravos relacionados a um saneamento ambiental inadequado. Brasília, DF: Ministério da Saúde.

Fundação Nacional de Saúde. (2019). Programa Nacional de Saneamento Rural (PNSR). Brasília, DF: Ministério da Saúde. Retrieved from http:// www.funasa.gov.br/documents/20182/38564/ MNL_PNSR_2019.pdf/08d94216-fb09-468e-ac98afb4ed0483eb

Giovanella, L. (1991). As origens e as correntes atuais do enfoque estratégico em planejamento de saúde na América Latina. Cadernos de Saúde Pública, 7(1), 26-44.

Gottems, L. B. D., Pires, M. R. G. M., Calmon, P. C. D. P., \& Alves, E. D. (2013). O modelo dos múltiplos fluxos de Kingdon na análise de políticas de saúde: aplicabilidades, contribuições e limites. Saúde Soc., 22(2), 511-520. 
Hall, P. A. (1993). Policy paradigms, social learning and the state: the case of economic policy making in Britain. Comparative Politics, 25(3), 275-296.

Howllet, M., Ramesh, M., \& Perl, A. (2013). Política pública: seus ciclos e subsistemas: uma abordagem integral. Rio de Janeiro, RJ: Elsevier.

Instituto Brasileiro de Geografia e Estatística. (1981). Censo Demográfico 1980. Rio de Janeiro, RJ: Author.

Instituto Brasileiro de Geografia e Estatística. (2011). Censo Demográfico 2010. Rio de Janeiro, RJ: Author.

Instituto de Planejamento Econômico e Social. (1985). Nota Técnica n. 018, de 25 de março de 1985. Projeto Nacional de Saneamento Rural. Brasília, DF: Author.

Instituto de Planejamento Econômico e Social. (1989a). Projeto Local de Saneamento Rural (Vol. 1, Série Saneamento Rural). Brasília, DF: Author.

Instituto de Planejamento Econômico e Social. (1989b). Bases para formulação de políticas e programas em saneamento rural (Vol. 2 Série Saneamento Rural). Brasília, DF: Author.

Instituto de Planejamento Econômico e Social. (1989c). Subsídios para elaboração de programas estaduais de saneamento rural (Vol. 3, Série Saneamento Rural). Brasília, DF: Author.

Joint Monitorig Programme. (2019). Progress on household drinking water, sanitation and hygiene 2000-2017: special focus on inequalities. New York, NY: United Nations Children's Fund (UNICEF) and World Health Organization (WHO). Retrieved from https://washdata.org/sites/default/files/ documents/reports/2019-07/jmp-2019-washhouseholds.pdf

Jones, M. D., Peterson, H. L., Pierce, J. J., Herweg, N., Bernal, A., Raney, H. L. ... Zahariadis, N. (2016). A river runs through it: a Multiple Streams metareview. Policy Studies Journal, 44(1), 13-36.

Kingdon, J. W. (1995). Agendas, alternatives and publics policies (2a ed). New York, NY: Harper Collins.

Lei n. 11.445, de 5 de janeiro de 2007. (2007). Estabelece diretrizes nacionais para o saneamento básico; altera as Leis nos 6.766, de 19 de dezembro de $1979,8.036$, de 11 de maio de 1990, 8.666, de 21 de junho de 1993, 8.987, de 13 de fevereiro de 1995; revoga a Lei no 6.528, de 11 de maio de 1978; e dá outras providências. Brasília, DF. Retrieved from http://www.planalto.gov.br/ccivil_03/_ato20072010/2007/lei/111445.htm

Lima, N. T. (2002). O Brasil e a Organização Pan-Americana da Saúde: uma história de três dimensões. In J. Finkelman. (Org.), Caminhos da saúde pública no Brasil (pp. 23-116). Rio de Janeiro, RJ: Fiocruz.

Liu, X., Lindquist, E., Vedlitz, A., \& Vincent, K. (2010). Understanding local policymaking: policy elites' perceptions of local agenda setting and alternative policy selection. Policy Studies Journal, 38(1), 69-91.

Luz, M. T. (1991). Notas sobre as políticas de saúde no Brasil de 'transição democrática': anos 1980. Physis: Revista de Saúde Coletiva, 1(1), 77-96.

Machado, J. C., Cotta, R. M. M., \& Soares, J. B. (2015). Reflexões sobre o processo de municipalização das políticas de saúde: a questão da descontinuidade político-administrativa. Interface - Comunicação, Saúde, Educação, 19(52), 159-170.

Mannheimer, L. N., Lehto, J., \& Ostlin, P. (2007). Window of opportunity for intersectoral health policy in Sweden: open, half-open or half-shut? Health Promotion International, 22(4), 307-315.

Mauti, J., Gautier, L., Neve, J. W., Beiersmann, C., Tosun, J., \& Jahn, A. (2019). Kenya's Health in All Policies strategy: a policy analysis using Kingdon's multiple streams. Health Research Policy and Systems, 17(15), 1-12.

Menicucci, T., \& D’Albuquerque, R. (2018). Política de saneamento vis-à-vis à política de saúde: encontros, desencontros e seus efeitos. In L. Heller. (Org.), Saneamento como política pública: um olhar a partir dos desafios do SUS (pp. 9-52). Rio de Janeiro, RJ: Fiocruz.

Paim, J., Travassos, C., Almeida, C., Bahia, L., \& Macinko, J. (2011). The Brazilian health system: history, advances, and challenges. Lancet, 377(9779), 1778-1797.

Paiva, C. H. A. (2016). O sertão na saúde e na formação de trabalhadores setoriais: contextos, 
atores e ideologias (1920-1970). Saúde em Debate, 40(110), 224-233.

Paiva, C. H. A., Pires-Alves, F., \& Hochman, G. (2008). A cooperação técnica OPAS-Brasil na formação de trabalhadores para a saúde (1973-1983). Ciência \& Saúde Coletiva, 13(3), 929-940.

Paiva, C. H. A., \& Teixeira, L. A. (2014). Reforma sanitária e a criação do Sistema Único de Saúde: notas sobre contextos e autores. História, Ciências, Saúde - Manguinhos, 21(1), 15-35.

Pereira, J. M. (2015). Poder, política e dinheiro: a trajetória do Banco Mundial entre 1980 e 2013. In J. M. Pereira, \& M. Pronko. (Org.), A demolição de direitos: um exame das políticas do Banco Mundial para a educação e a saúde (1980-2013) (pp. 19-64). Rio de Janeiro, RJ: Fiocruz.

Perz, S. G. (2000). The rural exodus in the context of economic crisis, globalization and reform in Brazil. International Migration Review, 34(3), 842-881.

Portaria Interministerial N. 55, de 19 de dezembro de 1984. (1984). Brasília, DF: Secretaria de Planejamento da Presidência da República, Ministério do Interior e Ministério da Saúde.

Portaria Interministerial N. 30, de 28 de fevereiro de 1985. (1985). Brasília, DF: Secretaria de Planejamento da Presidência da República, Ministério do Interior e Ministério da Saúde.

Portaria N. 3.174, de 02 de dezembro de 2019. (2019). Dispõe sobre o Programa Nacional de Saneamento Rural e dá outras providências. Brasília, DF: Ministério da Saúde.
Rezende, S., \& Heller, L. (2008). O saneamento no Brasil: políticas e interfaces (2a ed.). Belo Horizonte, MG: Editora UFMG.

Risi, J. B., Jr., \& Nogueira, R. B. (2002). As condições de saúde no Brasil. In J. Finkelman (Org.), Caminhos da saúde pública no Brasil (pp. 117-234). Rio de Janeiro, RJ: Fiocruz.

Saiani, C. C. S., \& Toneto, R., Jr. (2010). Evolução do acesso a serviços de saneamento básico no Brasil (1970 a 2004). Economia e Sociedade, 19(1), 79-106.

Silva, F. C. T. (1990). A modernização autoritária: do golpe militar à redemocratização (1964/1984). In M. Y. Linhares (Org.), História geral do Brasil (4a ed., pp. 273-303). Rio de Janeiro, RJ: Editora Campus.

Smith, A., Porter, J. J., \& Upham, P. (2016). 'We cannot let this happen again': reversing UK flood policy in response to the Somerset Levels floods, 2014. Journal of Environmental Planning and Management, 60(2), 351-369.

Sumida, S. (2017). Agenda setting in multilateral contexts: the example of the Decade of Education for Sustainable Development. Globalisation, Societies and Education, 15(4), 381-396.

Vilas, C. M. (2015). O Banco Mundial e a reforma do Estado na América Latina: fundamentos teóricos e prescrições políticas. In J. M. Pereira, M. Pronko (Org.), A demolição de direitos: um exame das políticas do Banco Mundial para a educação e a saúde (1980-2013) (pp. 65-89). Rio de Janeiro, RJ: Fiocruz.

Zahariadis, N. (1998). Comparing three lenses of policy choice. Policy Studies Journal, 26(3), 434-448. 


\section{Nathalia Roland}

https://orcid.org/0000-0002-9823-6657

Ph.D. student in Water Supply and Sanitation, Environment and Water Resources Program at Federal University of Minas Gerais. E-mail: nathaliaroland@outlook.com

\section{Léo Heller}

https://orcid.org/0000-0003-0175-0180

Researcher at René Rachou Institute. E-mail: leo.heller@fiocruz.br

\section{Sonaly Rezende}

https://orcid.org/0000-0002-5282-0938

Associate Professor in Department of Sanitary and Environmental Engineering and Postgraduate Program in Water Supply and Sanitation, Environment and Water Resources at Federal University of Minas Gerais.

E-mail: srezende@desa.ufmg.br 